\title{
Gambaran Ketahanan Hidup (Kesintasan) Satu Tahun Pasien Koinfeksi TB-HIV Berdasarkan Waktu Awal Pengobatan Antiretroval (ARV) pada Fase Lanjut di Rumah Sakit Penyakit Infeksi (RSPI) Prof. Dr. Sulianti Saroso Periode Januari 2011-
} Mei 2014

Description of 1-Years Survival Patient with TB-HIV Based on Preliminary Treatment Antiretroval (ARV) in Advanced Phase at Infectious Diseases Hospital Prof. Dr. Sulianti Saroso Period January 2011-May 2014

\author{
Siti Maemun ${ }^{1 *}$, Syahrizal Syarif ${ }^{2}$, Adria Rusli $^{1}$, Renti Mahkota ${ }^{2}$ \\ ${ }^{1}$ Rumah Sakit Penyakit Infeksi (RSPI) Prof. Dr. Sulianti Sarosos Jakarta \\ ${ }^{2}$ Departemen Epidemiologi, Fakultas Kesehatan Masyarakat, Universitas Indonesia, \\ ${ }^{*}$ Korespondensi Penulis : \\ Siti Maemun \\ Email : muntee83@gmail.com
}

\begin{abstract}
Abstrak
Latar Belakang : Human Immunodeficiency Virus (HIV) merupakan jenis retrovirus yang menginfeksi sistem kekebalan tubuh manusia yang menyebabkan Acquired Immunodefiency Syndrome (AIDS),. Kehadiran kuman TB menyebabkan progresivitas kasus ko-infeksi TB-HIV bertambah buruk sehingga mengancam jiwa penderitanya. Penelitian ini bertujuan untuk mengetahui gambaran kesintasan satu tahun pasien ko-infeksi TB-HIV berdasarkan waktu awal pengobatan ARV.

Metode : Penelitian ini menggunakan desain kohort retrospektif di RSPI Prof. Dr. Sulianti Saroso tahun 2013-2015. Sumber data yang digunakan berasal dari penelusuran pada register pra ARV dan ARV, Form TB 01, buku monitoring ARV, monitoring farmasi ARV, pelacakan ikhtisar ARV dan status rekam medis. Pengumpulan data melibatkan petugas Pokja HIV/AIDS dan dokter (validasi diagnosa dan kovariat) yang di blind atas hipotesis penelitian.

Hasil : Probabilitas ketahanan hidup kumulatif satu tahun pasien ko-infeksi TB-HIV yang mendapatkan awal pengobatan ARV di RSPI Prof. Dr. Sulianti Saroso periode Januari 2011-Mei 2014 adalah 81,5\%. Probabilitas ketahanan hidup pasien TB-HIV berdasarkan waktu awal menunjukan bahwa ketahanan hidup satu tahun pada pasien yang mendapatkan pengobatan ARV pada fase intensif adalah $89,1 \%$ dan pada pasien yang mendapatkan pengobatan ARV pada fase lanjut adalah $74,5 \%$.

Kesimpulan : Pasien ko-infeksi TB-HIV yang mendapatkan ARV pada fase intensif cenderung memiliki probalitas ketahanan hidup yang lebih besar di tahun pertama dibandingkan pasien ko-infeksi TB-HIV yang mendapatkan ARV pada fase lanjut.
\end{abstract}

Kata Kunci : Kesintasan, Koinfeksi TB-HIV, Antiretroviral (ARV)

\begin{abstract}
Background : Human Immunodeficiency Virus (HIV) is a type of retrovirus that infects the human immune system that causes Acquired Immunodefiency Syndrome (AIDS). The presence of TB germs cause progression of cases of co-infection of TB-HIV getting worse so threatening sufferers. This study aims to reveal the one-year survival rate of patients co-infected TB-HIV based on time start of antiretroviral treatment.
\end{abstract}


Methods : This study used a retrospective cohort design in RSPI Prof. Dr. Sulianti Saroso years 20132015. The data used comes from searches on the register of pre ARV and ARV form, TB Form, the book ARV monitoring, monitoring of pharmaceutical drugs, ARV overview and status tracking of medical records. The data collection involves the officer HIV / AIDS and the doctor (validation diagnosis and covariates) were in blind on the research hypothesis.

Results : The cumulative probability of survival for one year patients co-infected TB-HIV get antiretroviral treatment early in RSPI Prof. Dr. Sulianti Saroso period January 2011-May 2014 was 81.5\%. The probability of survival for patients of TB-HIV based on the initial time showed that one-year survival in patients receiving antiretroviral treatment in the intensive phase was $89.1 \%$ and in patients receiving antiretroviral treatment in advanced phases was $74.5 \%$.

Conclusion : Co-infected TB-HIV patients get antiretroviral drugs in the intensive phase tend to have a probability of survival is greater in the first year compared to co-infection TB-HIV patients get antiretroviral drugs in the advanced phase.

Keyword : Survival, TB-HIV co-infection, Antiretroviral (ARV)

\section{Pendahuluan}

Proporsi kasus ko-infeksi TB-HIV sangat bervariatif dan tersebar di belahan wilayah di dunia. Sekitar $41 \%$ di benua Afrika, 14\% Amerika, Eropa 8\%, Mediterania dan Pasifik Barat kurang dari 3\% dan Asia Tenggara 6\%.

Sumber data WHO menyebutkan bahwa Indonesia mengalami peningkatan kasus yang signifikan dimana pada tahun 2013 TB dengan status HIV positif sekitar 7,5\%, sedangkan tahun 2012 hanya mencapai 3,3\%. Tetapi Indonesia termasuk negara dengan peringkat terendah dalam hal cakupan pemeriksaan HIV pada pasien TB yaitu $2 \%$. Namun demikian TB masih menjadi infeksi oportunistik (IO) terbanyak walaupun ada kecenderungan penurunan kasus dari seluruh 10 yang terjadi pada ODHA yaitu 49\% (2010), 39,38\% (2013) terakhir 28,04\% (sampai dengan September 2014). ${ }^{1,2}$
Deteksi dan pengobatan TB yang adekuat dan memadai akan memperpanjang kehidupan ODHA dan mengurangi beban kesakitan TB. Semua kasus TB pada ODHA harus memulai pengobatan TB sesuai dengan pedoman program TB nasional dan sangat tergantung pada kriteria kelayakan diagnosa yang berlaku di negara tertentu. Selain itu semua ODHA yang memiliki TB harus diberikan pengobatan antiretroviral sesegera mungkin.3.4 Berdasarkan pedoman WHO tahun 2010, pengobatan ARV seharusnya segera dimulai setelah masa toleransi pengobatan TB yaitu sedini mungkin (2 minggu) tetapi idealnya tidak lebih dari 8 minggu setelah pengobatan OAT dimulai ${ }^{8}$. Inisiasi pengobatan ARV selama pengobatan OAT membuktikan dapat menurunkan kematian dibandingkan menunda sampai pengobatan OAT lengkap, tanpa melihat CD4-nya., ${ }^{5,6}$. 
Keterlambatan dalam memulai ARV pada koinfeksi TB-HIV akan meningkatkan mortalitas sedangkan pemberian ARV secara terintegrasi dengan OAT atau pemberian yang terlalu dini akan meningkatkan kemungkinan interaksi obat, toksisitas dan juga menurunkan kepatuhan minum obat sehingga waktu yang tepat untuk memulai ARV masih menjadi perdebatan $^{5,8}$. Keputusan untuk memulai ARV pada ko-infeksi TB-HIV tergantung pada indikator infeksi oportunistik yang lain. Pada TB ekstra paru dan TB paru dengan CD4 $<200$ $\mathrm{sel} / \mathrm{mm}^{3}$ disarankan secepatnya minimal 2-8 minggu setelah terapi OAT sedangkan pada CD4 $>200 \mathrm{sel} / \mathrm{mm}^{3}$ dianjurkan terapi ARV setelah selesai fase awal ${ }^{4}$. Studi di Malaysia membuktikan bahwa faktor prediktor yang menyebabkan kematian pasien ko-infeksi TB-HIV selama pengobatan TB, yaitu nilai hitung CD4 <200 $\mathrm{sel} / \mathrm{mm} 3$, pasien dengan $\geq 3$ Infeksi Oportunistik (IO), peningkatan per $10^{3}$ jumlah sel darah putih per mililiter (lekosit). Sedangkan pasien ko-infeksi TB-HIV yang tidak menerima terapi ARVmemiliki hazard 3,89 kali mengalami kematian dibandingkan yang menerima ARV (aHR 3,89; $95 \% \mathrm{Cl}: 1,2-12,63)^{9}$.

Keberadaan ko-infeksi TB menambah beban bagi pasien
HIV/AIDS, berdasarkan beberapa studi yang membahas ketahanan hidup pasien ko-infeksi TB-HIV, fakta menyatakan bahwa pengobatan ARV sebagai salah satu faktor yang sangat berpengaruh. Namun tertundanya waktu awal pengobatan ARV pada pasien ko-infeksi TB-HIV merupakan tantangan demi keberhasilan program kolaborasi TB-HIV. Pada enam bulan pertama, pengobatan ini sangat penting bagi perubahan klinis dan imunitas pasien. Risiko kematian paling besar pada tiga bulan pertama setelah pemberian ARV, terlebih dengan adanya komorbiditas lain. Informasi mengenai gambaran kesintasan pasien koinfeksi TB-HIV masih jarang diteliti, khususnya di Indonesia, sehingga perlu dilakukan penelitian tentang gambaran kesintasan pasien koinfeksi TB-HIV berdasarkan waktu awal pengobatan ARVdi RSPI Prof. Dr. Sulianti Saroso periode Januari 2011-Mei 2014.

\section{Metode}

Penelitian menggunakan metode deskriptif dengan analisis survival. Penelitian ini menggunakan populasi kohort dinamik (dynamic cohort). Penelitian dilakukan di Rumah Sakit Penyakit Infeksi (RSPI) Prof. Dr. Sulianti Saroso Jakarta pada bulan Mei-Juni 2015. Populasi dalam penelitian ini adalah semua pasien 
koinfeksi TB-HIV yang belum mendapat ARV (naive ARV) tetapi telah mendapat OAT yang memenuhi kriteria inklusi dan kriteria ekslusi. Kriteria inklusi adalah pasien HIV berusia $\geq 15$ tahun. pasien koinfeksi TB-HIV, dengan diagnosa klinisi HIV (+) dan TB kategori 1 dan kategori 2, yang mendapat OAT di fasilitas kesehatan tetapi belum terapi ARV (naive ARV). Sampel sebanyak 275 pasien yang diambil dengan teknik total sampling.

Sumber data berasal dari penelusuran register pra ARV dan ARV, Form TB 01, buku monitoring ARV, monitoring farmasi ARV, pelacakan ikhtisar ARV dan status rekam medis. Pengumpulan data melibatkan petugas Pokja HIV/AIDS dan dokter (validasi diagnosa dan kovariat) yang di blind atas hipotesis penelitian. Penelitian ini telah mendapatkan keterangan exempted dari Komite Etik Rumah Sakit Penyakit Infeksi Prof. Dr. Sulianti Saroso Jakarta.

\section{Hasil}

Hasil penelitian diketahui bahwa dari 275 orang subyek penelitian dengan koinfeksi TB-HIV, sebagian besar adalah yang mendapatkan pengobatan ARV pada fase intensif yaitu sebanyak 145 orang (52,73\%). Hasil dapat dilihat pada tabel 1.
Tabel 1. Distribusi Frekuensi Subyek Penelitian Berdasarkan Waktu Awal Pengobatan ARV

\begin{tabular}{lcc}
\hline Waktu Awal & $\mathrm{n}$ & $\%$ \\
Pengobatan ARV & & \\
\hline Intensive & 145 & 52,73 \\
Lanjut & 130 & 47,27 \\
\hline Jumlah & 275 & 100 \\
\hline
\end{tabular}

Hasil distribusi frekuensi pasien koinfeksi TB-HIV berdasarkan variabel independen utama dan variabel kovariat berdasarkan event dan sensor. Dari 275 subyek penelitian yang diamati, terdapat $49(17,82 \%)$ pasien yang mengalami event (meninggal) dan 226 (82,18\%) orang yang hidup atau loss to follow up. Berdasarkan waktu awal pengobatan ARV, yang mengalami event lebih tinggi pada kelompok fase intensif, yaitu sebesar $24,1 \%$ dari pada kelompok fase lanjut. Hasil dapat dilihat pada tabel 2.

Tabel 2. Distribusi Frekuensi Subyek Penelitian Berdasarkan Waktu Awal Pengobatan ARV terhadap Status Kematiannya.

\begin{tabular}{lcccccc}
\hline \multirow{2}{*}{ Fase } & \multicolumn{2}{c}{ Event } & \multicolumn{2}{c}{ Sensor } & \multicolumn{2}{c}{ Total } \\
\cline { 2 - 7 } & $\mathrm{n}$ & $\%$ & $\mathrm{n}$ & $\%$ & $\mathrm{n}$ & $\%$ \\
\hline Intensive & 35 & 24,1 & 110 & 75,9 & 145 & 100 \\
Lanjut & 14 & 10,7 & 116 & 89,3 & 130 & 100 \\
\hline
\end{tabular}

Lama pengamatan dalam penelitian ini adalah satu tahun (365 hari), sedangkan kontribusi waktu yang diberikan oleh setiap subyek adalah berbeda. Sementara itu probabilitas kumulatif pasien koinfeksi TB-HIV keseluruhan berbeda dengan koinfeksi TB-HIV pada dua kelompok. Berdasarkan gambar 1, probabilitas 
ketahanan hidup kumulatif pasien koinfeksi TB-HIV keseluruhan selama satu tahun (365 hari) adalah 81,5\%. Angka tersebut diinterpretasikan bahwa dari 100 pasien koinfeksi TB-HIV yang dapat bertahan hidup hingga satu tahun pengamatan sebanyak 81 orang. Sementara itu probabilitas ketahanan hidup satu tahun pada kelompok fase lanjut adalah $74,5 \%$ lebih rendah dari kelompok fase intensif $89,1 \%$.
Kedua kurva Kaplan Meier tidak berpotongan selama masa pengamatan studi. Pada kelompok fase lanjut, tampak setelah sekitar hari ke 100 kurva probabilitas ketahanan hidup terus menurun perlahan, sedangkan pada kelompok fase intensif kurva cenderung melandai, artinya probabilitas ketahanan hidup kelompok fase lanjut lebih rendah dibandingkan kelompok fase intensif.

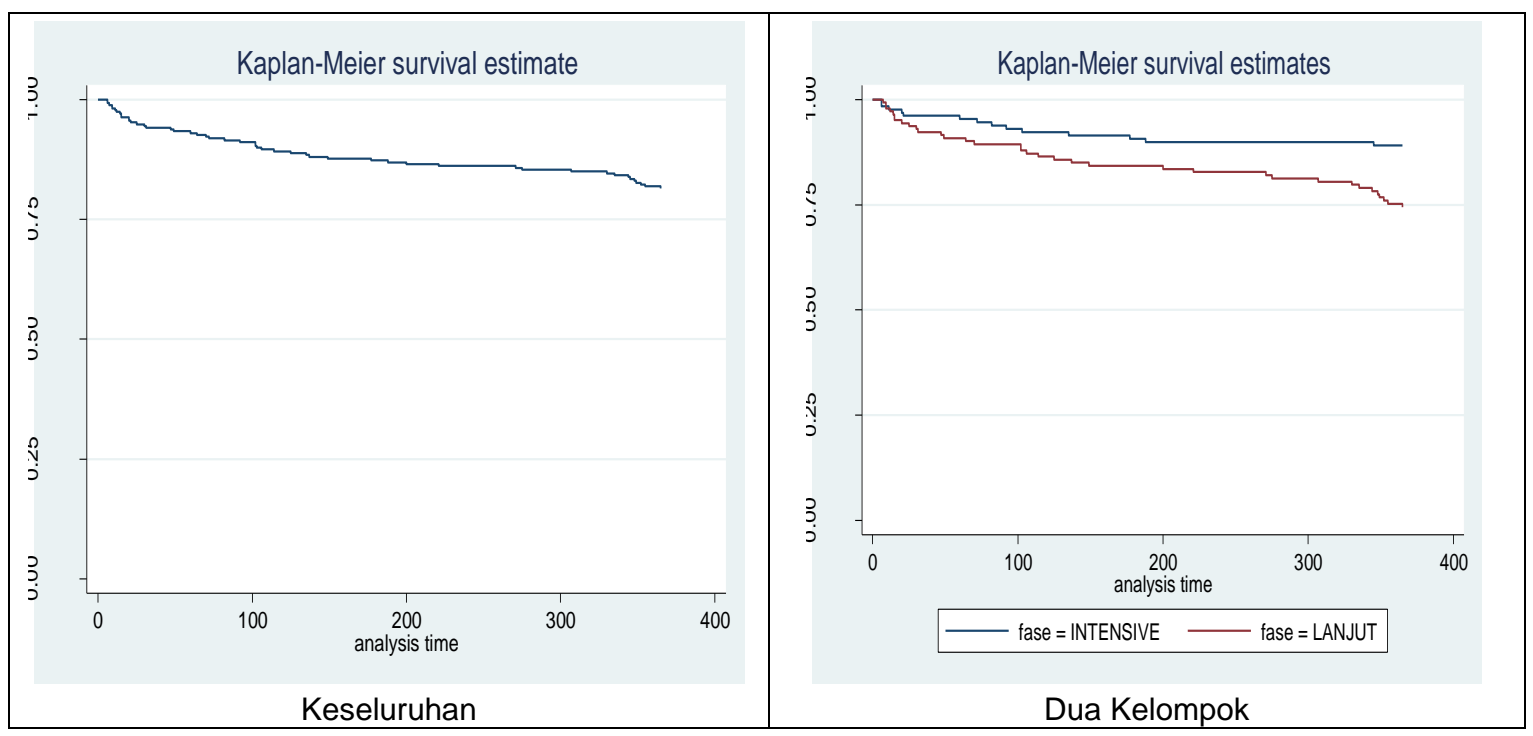

Gambar 1. Probabilitas Kumulatif Kesintasan 1 Tahun Pasien Koinfeksi TB-HIV di RSPI Prof. Dr. Sulianti Saroso Periode Januari 2013-Mei 2014

Semua subyek dalam penelitian memberikan kontribusi terhadap waktu ketahanan hidup keseluruhan populasi pada studi ini, dengan masa pengamatan 365 hari, rerata lama ketahanan hidup adalah 323 hari. Dari 275 subyek yang diamati sebanyak 49 pasien mengalami kematian, 205 pasien hidup dan 21 pasien hilang dari pengamatan (Tabel 3).

Tabel 3. Probabilitas Kesintasan Keseluruhan 1 Tahun Pasien Koinfeksi TB-HIV yang Mendapat ARV di RSPI-SS

\begin{tabular}{lcccc}
\hline \multicolumn{1}{c}{ Variabel Terikat } & $\mathrm{n}$ & $\begin{array}{c}\text { Persentase } \\
(\%)\end{array}$ & Mean & Min-Max \\
\hline Survival (time at risk) & 226 & 82,2 & 323 & $0-365$ \\
Hidup/hilang & 49 & 17,8 & & \\
Meninggal & & & & \\
\hline
\end{tabular}




\section{Pembahasan}

Hasil analisis terhadap ketahanan hidup pasien koinfeksi TB-HIV yang mendapat awal pengobatan ARV di RSPI-SS periode Januari 2011-Mei 2014 secara keselurahan pasien yang hidup/loss follow up sebanyak 226 pasien $(82,2 \%)$ dan meninggal dunia (event) sebanyak 49 pasien (17,8\%). Probabilitas ketahanan hidup satu tahun adalah $81,50 \%$. Probabilitas ketahanan hidup satu tahun dalam penelitian ini lebih tinggi dari probabilitas ketahanan hidup pasien HIV/AIDS yang pernah diobservasi, Rumah Sakit Kanker Dharmais, RSUP Fatmawati dan di RSKO Jakarta yang menemukan probabilitas ketahanan hidup satu tahun pasien HIV/AIDS sebesar $66,4 \%, 79,4 \%$ dan $54,46 \%$. Namun populasi penelitian di RSKO tidak mempertimbangkan status terapi ARV, sementara pada penelitian ini probabilitas ketahanan hidup pasien koinfeksi TB-HIV yang menjalani terapi ARV, maka kemungkinan probabilitas ketahanan hidup di ketiga RS tersebut lebih rendah. Penelitian yang dilakukan di rumah sakit yang sama di RSPI-SS, menemukan probabilitas kumulatif ketahanan hidup satu tahun pasien HIV/AIDS yang mendapat terapi ARV adalah sebesar $86 \%{ }^{10}$. Angka yang tidak jauh berbeda dengan studi Meilani bahwa probabilitas ketahanan hidup satu tahun adalah 84,12\%. Angka ketahanan hidup pada studi ini lebih rendah dari dua studi sebelumnya mengingat populasi pada studi ini adalah semua pasien koinfeksi TB-HIV yang mayoritas berada pada stadium HIV/AIDS III dan IV. ${ }^{11}$

Probabilitas ketahanan hidup kumulatif pasien koinfeksi TB-HIV yang mendapat ARV selama satu tahun (365 hari) adalah $81,5 \%$. Sementara itu probabilitas ketahanan hidup pasien koinfeksi TB-HIV berdasarkan waktu awal pengobatan ARV di RSPI-SS adalah $89,1 \%$ pada fase intensif dan $74,5 \%$ pada fase lanjut. Hasil studi sebelumnya di RSPI SS tahun 2010 didapatkan bahwa ODHA dengan koinfeksi TB, sebelum mendapatkan ARV berisiko 3,57 kali dibandingkan ODHA tanpa TB dan probabilitas ketahanan hidup satu tahun pertama adalah 77,3\% (95\% Cl: 65\%-86\%) lebih rendah dibandingkan ODHA tanpa TB yaitu 93,7\% (95\%Cl: 85\%-97\%) ${ }^{10}$.

Sementara itu hasil studi Meilani menjelaskan bahwa probabilitas ketahanan hidup satu tahun pasien koinfeksi TB-HIV yang mendapat ARV adalah 82,24\%. Studi di Brazil menyebutkan bahwa $89 \%$ risiko kematian menurun pada pasien yang mendapat HAART pada fase intensif dibandingkan pada pasien yang 
mendapat HAART pada fase lanjut. Hasil studi eksperimen yang dilakukan di Kamboja menemukan bahwa 34\% risiko kematian berkurang pada pasien ko-infeksi TB-HIV dengan CD4 $<50$ sell $/ \mathrm{mm}^{3}$ yang mendapat ARV pada fase lanjut dan $72 \%$ risiko kematian berkurang pada pasien koinfeksi TBHIV dengan CD4 $<50$ sell $/ \mathrm{mm}^{3}$ yang mendapat ARV pada fase intensif. Pada pasien yang mendapat ARV di fase intensif, 12,9\% mengalami kematian sedangkan pada pasien yang mendapat ARV di fase lanjut 16,1\% mengalami kematian $(95 \% \mathrm{Cl}:-1,8-$ $8,1 ; p=0,45)^{11,12}$.

Pedoman pengobatan ARV WHO (2014) juga menyebutkan bahwa kematian meningkat dalam tiga bulan pertama setelah pengobatan ARV, selain itu studi eksperimen yang dilakukan tahun 2006 melaporkan bahwa, 63\% kematian terjadi pada 6 bulan pertama terapi ${ }^{1}$. Tampak kematian terbanyak terjadi dalam enam bulan pertama. Hal serupa dijumpai pada penelitian Anggraeni pada tahun 2010 dimana didapatkan kematian sebesar $71,43 \%$ terjadi dalam enam bulan pertama setelah orang dengan HIV/AIDS mendapat pengobatan ARV, pada empat bulan pertama terjadi $80 \%$ kematian dan pada tiga bulan pertama $60 \%$ kematian $^{10}$.
Atas bukti studi sebelumnya dan hasil analisis yang telah dilakukan, bahwa risiko kematian meningkat pada pasien HIV/AIDS yang mendapatkan ARV pada 6 bulan pertama, terlebih lagi dengan kehadiran infeksi M.tuberculosis yang akan menurunkan probabilitas ketahanan hidup ODHA dalam satu tahun pertama. Progresifitas prognosis kedua infeksi ini akan semakin parah apabila tertundanya pengobatan ARV pada pasien koinfeksi TB-HIV. Rekomendasi inisiasi pengobatan ARV pada pasien koinfeksi TB-HIV diharapkan dapat menurunkan angka kesakitan TB, menurunkan kekambuhan TB, sehingga dapat meningkatkan ketahanan hidup dan kualitas hidup pasien koinfeksi TB-HIV.

\section{Kesimpulan}

Pasien koinfeksi TB-HIV yang mendapatkan ARV pada fase intensif cenderung memiliki probalitas ketahanan hidup yang lebih besar di tahun pertama dibandingkan pasien koinfeksi TB-HIV yang mendapatkan ARV pada fase lanjut.

\section{Ucapan Terima Kasih}

Penulis mengucapkan terima kasih kepada institusi RSPI Prof Dr. Sulianti Saroso dan semua pihak yang 
terlibat dalam proses pengumpulan data.

\section{Daftar Pustaka}

1. World Health Organization (WHO). Global Tuberculosis Report. 2014.

2. Kemenkes RI. Statistik Kasus HIV/AIDS di Indonesia Dilapor s/d September 2014. Jakarta; 2014.

3. World Health Organization. Consolidated guidelines on the use of antiretroviral drugs for treating and preventing HIV infection. 2013;272.

4. Albrecht D, Altfeld M, Behrens G, Bredeek UF, Buhk T, Dickinson L, et al. HIV Medicine 2007 [Internet]. HIV Medicine. 2007. 818 p. Available from: www.HIVMedicine.com

5. Abdool Karim SS, Naidoo K, Grobler A, Padayatchi N, Baxter C, Gray A, et al. Timing of initiation of antiretroviral drugs during tuberculosis therapy. N Engl $J$ Med [Internet]. 2010;362(8):697-706. Available from:

http://eutils.ncbi.nlm.nih.gov/entre z/eutils/elink.fcgi?dbfrom=pubmed $\& i d=20181971 \&$ retmode $=$ ref $\& \mathrm{cmd}$ $=$ prlinks $\% 5$ Cnpapers $2: / /$ publicatio n/doi/10.1056/NEJMoa0905848

6. Cortes CP, Sterling TR, McGowan CC, Shepherd BE, Duda SN, Jenkins CA, et al. Duration of Anti-Tuberculosis Therapy and Timing of Antiretroviral Therapy Initiation: Association with Mortality in HIVRelated Tuberculosis. PLoS One. 2013;8(9):1-8.

7. Török ME, Thi N, Yen B, Thi T,
Chau $\mathrm{H}$, Thi $\mathrm{N}$, et al. Timing of Initiation of Antiretroviral Therapy in Human Immunodeficiency Virus ( HIV )- Associated Tuberculous Meningitis. Clin Infect Dis [Internet]. 2011;52(11):1374-83. Available from:

http://www.ncbi.nlm.nih.gov/pmc/ articles/PMC4340579/pdf/emss62280.pdf

8. Kiertiburanakul, S., Manosuthi, W., Sungkanuparph S. Optimal Timing Of Antiretroviral Therapy Initiation In Patients Coinfected With HIV And Tuberculosis. Expert Rev Clin Pharmacol. 2011;4:143-6.

9. Ismail I, Bulgiba A. Predictors of Death during Tuberculosis Treatment in TB/HIV Co-Infected Patients in Malaysia. PLoS One. 2013;8(8):1-7.

10. Anggraeni ND. Ketahanan Hidup Satu Tahun Pasien HIV/AIDS dengan Pengobatan Regimen ARV Lini Pertama Berdasarkan Jumlah CD4 Sebelum Pengobatan ARV di RSPI Prof. DR. Sulianti Saroso Tahun 20052010. Universitas Indonesia; 2010.

11. Melani. Pengaruh koinfeksi tuberkulosis terhadap kesintasan tiga tahun pasien HIV / AIDS yang mendapat terapi antiretroviral di Rumah Sakit penyakit infeksi Prof DR Sulianti Saroso tahun 2009-2011= Impact of tuberculosis co infection on three year survival among. $2011 ; 2011$.

12. Havlir D V, Kendall MA, Ive P, Kumwenda J, Swindells S, Qasba SS, et al. Timing of antiretroviral therapy for HIV-1 infection and tuberculosis. $N$ Engl J Med. 2011;365:1482-91. 